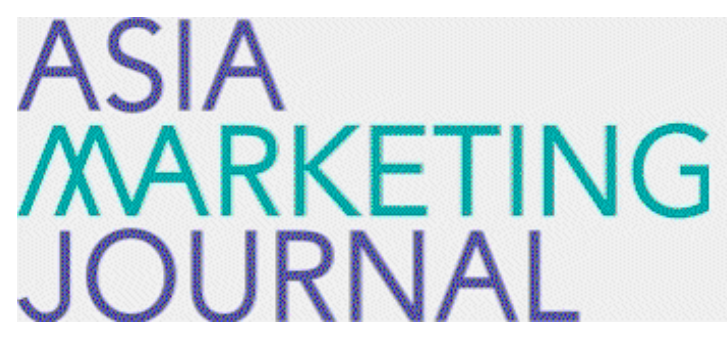

ASIA MARKETING JOURNAL

Volume 2 | Issue 4

Article 2

$12-1-2000$

\title{
관계지향적 고객의 구전 및 재구매의도에 대한 전반적 만족과 신뢰 및 몰입의 매개적 역할에 관한 연구
}

Nak Hwan Choi

Jin Ryeol Lee

Kwang Jin $\mathrm{Na}$

Follow this and additional works at: https://amj.kma.re.kr/journal

Part of the Marketing Commons

\section{Recommended Citation}

Choi, Nak Hwan; Lee, Jin Ryeol; and Na, Kwang Jin (2000) "관계지향적 고객의 구전 및 재구매의도에 대한 전반적 만족과 신뢰 및 몰입의 매개적 역할에 관한 연구," Asia Marketing Journal: Vol. 2 : Iss. 4 , Article 2. Available at: https://doi.org/10.53728/2765-6500.1050

This Article is brought to you for free and open access by Asia Marketing Journal. It has been accepted for inclusion in Asia Marketing Journal by an authorized editor of Asia Marketing Journal. 


\title{
관계지향적 고객의 구전 및 재구매의도에 대한
}

\section{전반적 만족과 신뢰 및 몰입의 매개적 역할에 관한 연구*}

\section{Mediating Roles of General-Satisfaction Trust and \\ Commitment on Word of Mouth and Repurchasing Intention of Relationship-oriented Customers}

\author{
최낙환(전북대학교 경영학부 교수) \\ cnh@moak.chonbuk.ac.kr \\ 나광진(전북대학교 경영학부 강사) \\ inny5322@hanmail.net \\ 이진렬(전북대학교 경영학부 강사) \\ comkim46@hanmail.net
}

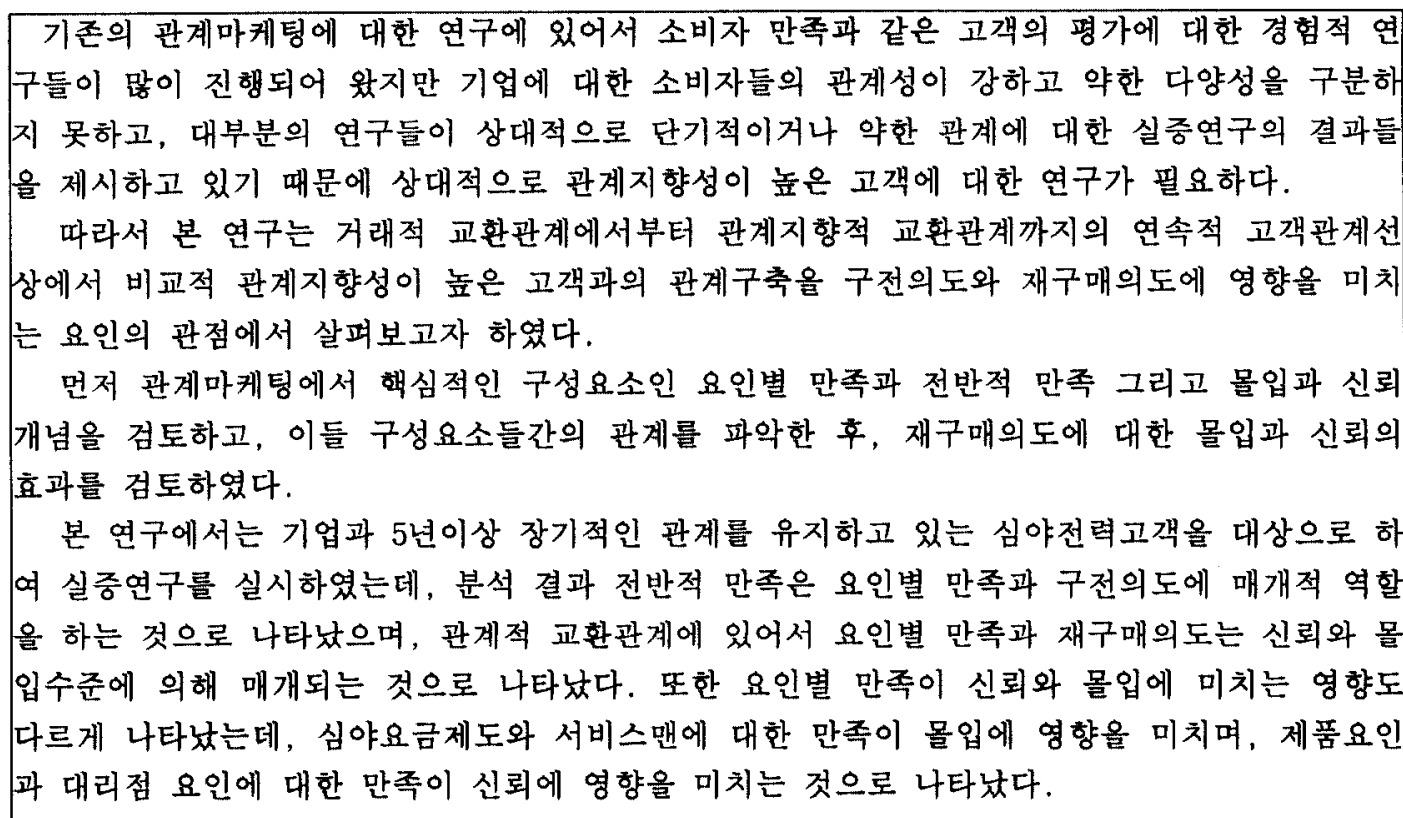

- 논문접수: 01.01 게재확정: 01.05 


\section{1. 서론}

기업에 대한 고객의 가치는 반복구매와 타 고객에 대한 구전에서 찾을 수 있다. 반복구매와 구전은 기업과의 지속적 거래를 설명하는 내용이기 때문에 관계마케팅적 연구를 필요로 한다.

관계 마캐팅(relationship marketing)에 대한 기존 연구의 입장은 거래적 교환관계에서부터 관계지향적 교환관계까지의 연속적 고객관계률 가정하고 있다(김주영, 함도훈, 김구성 2000; 오세조, 박진용, 한상린 1998; Dwyer, Schurr, and Oh 1987; Jackson 1985). Jackson(1985)은 기업이 교환에서 거래적 개념을 적용할 것인가 아니면 관계적 개념울 적용할 것인가는 기업스스로의 전략적 판단에 의해서 보다는 기업과의 관계에 대한 고객의 지향성에 따라서 달라져야함을 최초로 주장하였다. 이러한 Jackson(1985)의 아이디어를 바탕으로 하여 Anderson과 $\operatorname{Narus(1991)ㄴㅡㄴ~ㄱㅓㄹㅐㅈㅓㄱ~ㄱㅛㅎㅘㄴㅇㅔㅅㅓ~ㄱㅘㄴㄱㅖㅈㅓㄱ~ㄱㅛㅎㅘㄴㅇㅔ~ㅇㅣㄹㅡㄴㅡㄴ~ㅇㅕㄴㅅㅗㄱㅅㅓㄴㅅㅏㅇㅇㅢ~ㄱㅘㄴㅈㅓㅁㅇㅔㅅㅓ~}$ 고객을 분류해야 함을 주장하였다. 즉, 기업은 모든 고객이 똑같은 관계를 원하는 것이 아니기 때문에 거래 마케팅과 관계 마케팅을 동시에 추구할 필요성을 역설하고 있다.

거래적 교환은 최소한의 개인적 관계에 의해서 또는 차후의 교환에 대한 예측이나 의무감이 없이 상품이나 성과를 대가로 받고 구매자와 판매자가 불연속적으로 교환하는 것이다. 관계적 교환은 협동적 행동, 당사자간의 상호 조정, 교환의 이익공유, 그리고 미래의 교환에 대한 계힉 둥으로 설명된다. 그런데, Macneil(1980)은 순수한 거래적 교환은 찾아보기 어렵고 어떤 측면에서든지 관계개념이 구매자와 판매자간의 대부분 거래에 작용하고 있다고 하였다. 즉, 거래적 교환개념과 관계적 교환개념이 복합적으로 작용한다는 것이다.

거래/관계 연속체개념은 파트너쉽 개념의 발전을 유도하는 이론이나 저서에서도 나타나고 있다. Dwyer, Schurr and $\mathrm{Oh}(1987)$ 가 흔인 관계모형을 적용하여 교환관계의 발전을 설명한 것이 연속체 개념에 대한 매우 영향력 있는 근거가 된다.

따라서 기업측면에서 고객과의 관계에 있어서도, 위와 같온 기존연구들을 근거로 하면 고객과의 관계에 있어서 관계마케팅모형은 거래적 관계에서부터 관계지향적 관계까지의 연속선상에서 고객관계가 어떻게 다른지에 따라 달라질 수 있다는 점을 예상해 뵬 수 있다. 재구매의도와 구전은 연속선상에서 비교적 관계지향성이 강한 경우를 가정하고 있기 때문에 관계지향적 고객을 대상으로 연구를 수행할 필요가 있다.

그러나 기존에 관계마케팅을 다룬 많은 연구들(Berry 1995; Crosby, Evans and Cowles 1990; Morgan and Hunt 1999)이 그러한 연속적인 고객관계를 고려하지 못하고 단기적이거나 또는 특정시점에서의 고객과의 관계를 다루고 있고 상대적으로 장기적인 즉, 관계지향성이 높은 고객관계에 대한 연구는 빈약하다고 할 수 있다. 그런데 Garbarino and Johnson(1997)은 관계지향적 고객의 경우에 전반적 만족이 몰입과 신뢰의 선행요인이 아니라고 하고 거래지향적 고객의 경우와 차별화하였다. 따라서 관계지향성이 높은 경우 고객과의 관계마케텅모형은 기존의 모형과는 상이성을 나타낼 수 있다. 이를 위해 관계지향성이 높은 고객과의 관계마케팅모형구축에 펄요한 구성개념들에 대해 기존연구의 고찰을 통해 살펴볼 펄요가 있다.

따라서 본 연구에서는 교환관계에서부터 관계지향적 관계까지의 연속적 고객관계선상에서 비교적 관계지향성이 높은 고객과의 관계구축을 구전의도와 재구매의도에 영향을 미치는 요인의 관점에서 살펴보고자 한다. 왜나하면 재구매는 관계의 성과요소이며, 구전은 비용이 
들지 않는 고객채널이기 때문이다. 이를 위하여 본 연구의 실중분석을 위한 표본은 기업과 5년 이상 장기적인 관계를 유지하고 있는 심야전력고객을 대상으로 하였다.

이러한 관점예서 본 연구의 목적을 요약하면 다음과 같다.

첫째, 관계마케팅에서 핵심적인 구성요소인 요인별 만족과 전반적 만족 그리고 몰입과 신뢰개념을 검토한다. 둘째, 이들 구성요소들간의 관계를 검토한다. 셋째, 재구매의도에 대한 몰입과 신뢰의 효과를 검토한다

\section{2. 구성개념에 대한 이론적 고찰}

기존의 관계마케팅에 대한 연구에 있어서 소비자 만족과 같은 고객의 평가에 대한 경험적 연구들이 그 돟안 많이 진행되어 왔다지만 기업에 대한 소비자들의 관계성이 강하고 약한 다양성올 구분하지 못하고 대부분의 연구들이 상대적으로 단기적이거나 약한 관계에 대한 실중연구의 결과들을 제시하고 있기 때문에 상대적으로 관계지향성이 높은 고객에 대한 연구가 필요하다.

이러한 주장은 기업예 대한 고객의 관계지향성에 따라 고객의 만족이나 재구매의도에 영향을 미치는 요인들이 달라질 수 있다고 제기한 기존연구를 바탕으로 하고 있다. 예를 들어, 파트너쉅이론들은 강한 관계에 있는 소비자들은 높은 수준의 신뢰와 몰입올 가지고 있을 뿐 만 아니라 이러한 신뢰와 몰입은 그들 태도와 신념 구조의 중심을 이룬다고 주장하고 있다(Morgan and Hunt 1994). 또한 파트너 관계이론에서 중심적인 아이디어는 신뢰(trust)와 몰입(commitment)이 파트너를 단기적 고객과 반복거래 지향적 고객을 차별화 시키는 중요한 개념임을 지적하고 있다(Berry 1995; Webster 1992).

마케팅조직의 관점에서 소비자들의 의사결정은 고객 만족, 지갇ㄷㄴㄴ 서비스 품질, 지각된 가치, 신뢰, 그리고 몰입과 같은 좀 더 고차원적인 요인들에 의해서 영향을 받는다고 본다. 이러한 요인들에 대한 평가치는 특정 기업에 대한 소비자의 경험과 지식을 함축하고 또 소비자의 행동올 유발시킨다고 볼 수 있다. 과거 십여 년 동안 소비자 행동을 예측하는데 이용되는 변수 중에서 전반적인 고객 만족 변수는 중요한 변수로 인지되어 왔다. 그런데 관계마케팅 개념으로 초점이 이동되면서 신뢰(trust)와 몰입(commitment) 같은 새로운 개념으로 미래의 의도예측 요인은 보완되고 확대되었다. 이들 요인들에 대하여 살펴보고자 한다.

\section{1. 요인별 만족과 전반적 만족}

전반적 만족(overall satisfaction) 또는 누적적 만족(cumulative satisfaction)은 재화나 서비스에 대한 구매 및 소비 경헙에 근거한 전반적인 평가이다(Anderson, Fornell and Lehman 1994). 누적적 만족은 거래에 국한된 고객 만족, 즉 가장 최근의 거래 경협에 대한 구매후의 즉시적 판단이나 감정적 반웅인 고객 만족과 구별된다(Oliver 1993). 누적적 만족은 일시적이고 특정적인 만남에 국한된 평가나 감정에만 한정된 것이 아니고 기업에 대한 모든 경헙에 근거한 전반적인 만족수준으로 누적적 만족은 측정된다. 즉 전반적 만족은 누적개념으로 특정 제품이나 서비스에 대한 만족, 물적 설비와 같은 기업의 다양한 요인별 
측면에 대한 만족율 모두 포합하고 있다(Czepiel, Rosenberg and Akerele 1974).

\section{2. 신 뢰}

일반적으로 신뢰는 성공적인 관계에 대한 필수적인 구성요소로 간주된다(Berry 1995; Dwyer, Schurr and Oh 1987; Moorman, Deshpande and Zaltman 1993; Morgan and Hunt 1994). Moorman, Deshpande and Zaltman(1993)은 "사랍들이 믿는 교환 파트너에 기꺼이 의존할 수 있는 마음” 이라고 신뢰를 정의한다. 그들은 신뢰기대는 실행내용(전문적 지식), 신뢰도, 의도성에 대한 능력에서 기인된다고 했으며, Morgan and Hunt(1994)는 “교환 파트너의 성실성과 신뢰도에서 신용의 지각"으로 신뢰를 정의하였다. 이 두 가지 정의의 중요한 사항은 신뢰의 개념을 신용과 신뢰성으로 보았다는 것이다.

몰입과 마찬가지로 신뢰 역시 사화적 교환 (Fox 1974; Scanzoni 1979) 및 기타 분야에서 폭넓게 연구되어 왔다. 예를 들면, 조직 행동론 분야에서 “신뢰의 기준"에 관한 연구는 조직 경제학과 경영 이론을 구분하는 특성으로 간주되어 왔다 (Barney 1990; Donaldson 1990)

커뮤니케이션 분야에서 핵심적인 개념은 Hovland, Janis and Kelly(1953)에 의해 정의된 바와 같이, 정보원천의 신뢰성으로, 이는 수신자에 의한 송신자의 신뢰라고 정의되었다. 서비스 마케텅 분야에서 Berry와 Parasuraman(1991) 은 고객-기업간의 관계에서 신뢰의 중요성올 강조하고, 서비스 마케팅은 신뢰의 관리에 달려 있다고 보고 있는데 이는 소비자들은 일반적으로 서비스를 경헙하기 전에 구매하기 때문이라는 것이다.

전략적 제휴에 있어 Sherman(1992)은 “제휴의 성공에 가장 큰 장애는 신뢰의 부족이다"라고 결론지었고, 소매분야에 있어서 Berry(1993)는 "신뢰는 상표충성도의 기초이다" 라는 점을 강조하였다.

구매자-판매자 협상과정에서도, Schurr와 Ozanne(1985)는 협력적 문제 해결을 달성하는 과정 및 건설적인 대화에 있어서 신뢰가 중요하다는 것을 발견하였다. 앞에서 언급한 바와 같이 조직적 상황에서도, 그들은 역시 신뢰가 협상 당사자에 대해 높은 수준의 충성도(즉, 몰입)를 유발한다는 것을 발견하였다. 마지막으로 신뢰는 산업 마케팅과 구매 집단에 의해 수행된 연구에서도 중요한 것으로 간주되었다(Ford 1990; Hakansson 1982).

몇몇 연구에서 판매자와 같은 다른 관계자와의 성실과 정직을 신뢰로 강조하는 경향이 있는데(Crosby, Evans and Cowles 1990), Gwinner, Gremler and Bitner(1998)는 서비스 기업과 소비자 관계에서 특별한 대우 또는 사회적 이익보다 신용과 신뢰의 심리적인 이점이 더욱 중요하다고 제시하고 있다. 본 연구에서는 개인의 신뢰보다는 제공된 서비스의 신뢰성과 품질에서 소비자의 신용으로 얻어진 기업에 대한 소비자의 신뢰를 중점적으로 연구하였다.

\section{3. 몰 입}

신뢰와 비숫하게 몰입은 성공적인 오랜 관계에 대한 필수적인 구성요소로 생각된다(Dwyer, Schurr and Oh 1987; Morgan and Hunt 1994). 몰입은 "가치있는 관계를 유지하기 위한 지속적인 욕구”라고 정의되었다(Moorman, Zaltman and Deshpande 1992). Gundlach, Achrol and Mentzer(1995)는 몰입은 투자의 형태로 된 수단적 요소, 감정적인 몰입이나 심리적인 애착으로 표현될 수 있는 태도적 요소, 오랫동안 존재하는 관계롤 나타내는 일시적인 차원 둥 세 가지 요소로 구성되어 있다고 주장하였다. Anderson과 
Weitz(1992)는 “몰입이란 미래에 관계를 계속 유지하려고 하는 것이며, 그러한 관계를 유지하기 위해 단기간의 회생을 감수하려는 의지이다"라고 제안하였다.

조직에 대한 소비자 몰입의 본질을 정의하기 위한 한가지 접근법은 기업에 대한 고용자의 몰입과 관련된 조직 이론을 원용하는 것이다(O'Reilly and Chatman 1986). 몇몇의 기업에 대한 소비자 몰입 연구는 헬스크럽(Kelley and Davis 1994)이나 식품점(Bettencourt 1997)에 대한 소비자 몰입 요인을 측정하기 위하여 고용자 몰입의 척도를 수정 사용하였다.

\section{4. 재구매 의도와 구전의도}

미래의 재구매의도의 평가를 다루고 있는 기존연구에서는 재구매의도를 평가하는데 있어서 가장 예측력이 우수한 평가.오소가 무엇인지를 파악하고자 하는 것이 주요 관심사였다. 특히 Zeithaml, Berry and Parasuraman(1996)은 이와 관련하여 고객이 미래에 현재 거래관계를 맺고 있는 기업과 지속적으로 거래관계를 유지하려고 하는지 아니면 거래관계를 중단하려고 하는지와 관련된 미래행동의도의 중요성을 강조하였다.

한편, 친구나 동료는 어떤 다른 정보원천보다 소비자 선택에 더 큰 영향을 미칠 가능성이 있다(Assael 1984). 친구나 동료는 상업적 정보원보다 좀 더 믿을 수 있고 신뢰할 수 있기 때문에 강력한 영향요인이 된다. 또한 기업의 정보유통채널로서 구전경로는 비용을 수반하지 않는 경로이다. Hofsted(1980)는 우리나라를 대만, 홍콩, 멕시코, 일본 둥과 같이 집단주의적 문화를 가진 나라로 분류하였다. 집단주의적 가치를 가진 나라의 소비자들은 구매의사결정에 타인을 고려하며 제품구매와 소비에 대한 타인들의 반웅들을 신중하게 고려하는 타인지향적 성향을 가진다(Hawkins et al. 1998). 따라서 긍정적 구전의도는 관리되어야 할 중요한 요소이다.

\section{3. 가설의 설정}

\section{1. 전반적인 만족과 요인별 만족요인}

Czepiel, Rosenberg and Akerele(1974) 그리고 Westbrook(1981)은 기업에 대한 만족은 누적적인 개념으로 태도와 유사한 구성개념인데 그러한 구성개념은 그 기업의 사랍이나 제품 등과 같은 특정요인에 대한 만족으로 구성되어진다고 주장하였다. 예를 들면, Westbrook(1981)은 소매점에 대한 만족은 판매원, 상점 환경, 제품, 그리고 다른 요인에 대한 분리된 만족 평가의 누적된 배열이라고 제시하였다. Crosby와 Stephens(1987)는 생명 보헙에 대한 전체적인 만족은 대리인(서비스 제공자)이나 주요 서비스에 대한 만족처럽 여러 가지의 분리된 구성요소를 퉁해 달성된다고 하였다. 또한 최근에는 Oliver(1993), Rust, Zahorik and Keiningham(1995), Spreng, MacKenzie and Olshavsky(1996) 그리고 Mittal, Ross and Baldasare(1998)는 특정 제품이나 서비스 등과 같은 구성요인들에 대한 만족이 기업의 전반적인 만족을 설명하는 구성요인이라고 제시하고 있다.

이러한 논의에 따라 본 연구에서도 기업에 대한 전반적인 만족은 누적적인 태도를 결정하는 분리된 구성요인들에 대한 태도의 누적적인 합계라고 하는 기존연구의 입장을 
그대로 따르고 있다. 그러나 기업에 대한 전반적인 만족척도가 소비자의 미래행동과 재구매의도를 예측하는데 있어서 유용한 척도로 인정된다 할 지라도 서비스에 있어서는 어떠한 요인들이 전반적인 만족의 구성요소인지에 대한 연구는 그다지 연구된 바가 없다. 본 연구에서는 실중대상을 심야전력제품으로 하고 심야전력부분에서 전반적인 만족을 구성하는 요인은 심야전력요금제도 만족, 서비스맨에 대한 만족, 심야전력제품 만족, 대리점에 대한 만족 등과 같은 요인에 의해 영향을 받을 것으로 예상되기 때문에 전반적인 만족에 영향을 미치는 요소들을 심야전력요금제도 만족, 서비스제품에 대한 만족, 서비스맨에 대한 만족, 그리고 취급대리점의 물리적 환경에 대한 만족에 국한시킨다.

서비스 제공자의 중요성은 서비스 문헌들에서 다양하게 연구되어져 왔다. 이러한 기존연구돌에서 서비스에 대한 만족은 서비스제공자로서 서비스맨에 대한 만족에 초점을 두어왔는데(Czepeil 1990; Price, Arnould and Tierney 1995), 서비스맨에 대한 만족은 긍정적 평가를 반영하는 태도개념과 서비스의 질과 기술의 지각으로 간주된다.

또한 기존연구에서 서비스제품 자체에 대한 만족도 서비스에 대한 전반적인 만족을 결정하는 중요한 요인으로 간주되어 왔다(Crosby and Stephens 1987). 따라서 본 연구에서는 서비스에 대한 전반적인 만족이 서비스맨에 대한 만족뿐만 아니라 서비스제품 그 자체에 의해서도 영향을 받는다고 예상한다.

그리고 Bitner(1990)는 서비스 조직의 물리적인 환경이 서비스 조직에 대한 소비자의 궁극적인 만족에 영향을 미칠 수 있다고 주장하였다. 서비스의 무형성 때문에 일부 소비자는 전체적인 인상을 형성하는 것을 돕는 요인으로 물리적인 환경올 사용한다. 따라서 고객의 전체적인 만족은 대리점의 시설에 대한 만족수준에 따라 영향을 받는다고 예상할 수 있다.

따라서 심야전력고객이 심야전려제품기업에 대하여 형성하는 전반적인 만족은 심야전력요금제도와 심야전력제품에 대한 만족과 서비스맨에 대한 만족 그리고 대리점에 대한 만족정도에 따라 영향을 받을 것으로 예상되며 이를 바탕으로 다음 가설 1 을 설정하였다.

가설1 : 심야전력서비스구성요인에 대한 만족(심야전력요금제도 만족, 서비스맨에 대한 만족, 심야전력제품 만족, 대리검에 대한 만족)은 전반적인 기업만족에 긍정적인 영향을 미칠 것이다.

\section{2. 매개변수로서의 신뢰와 몰입}

Morgan과 Hunt(1994)는 관계성에 관한 푹넓온 마케팅 문헌고찰을 퉁하여, 신뢰와 몰입이 성공적인 관계적 교환에 주요 매개변수라는 것을 이론화하였다. 파트너와의 관계효익과 비용, 공유된 가치, 기회주의적 행동과 커뮤니케이션방법 둥이 신뢰와 몰입을 매개로 고객행동에 영향을 미침을 파악하였다. 본 연구에서는 이러한 이론을 기초로 하고 심야 전력 제품의 내구성 폭징에 의해 장기적 관계가 지속되기 때문에 기업에 대한 높은 관계지향성 또는 동반자 지향성(partnering orientation)을 지닌 소비자들의 포괄적인 평가에 있어서 전반적인 만족과 함께 신뢰와 몰입을 주요 매개변수로 제시하고 있다.

가설 1 온 전반적인 만족과 전반적인 만족의 선행요인간의 관계를 다루고 있는데 이렇게 전반적인 만족과 전반적인 만족의 선행요인과의 관계를 다룬 기존연구는 많다고 할 지라도 
이러한 선행요인들이 소비자의 신뢰와 몰입에 어떠한 영향을 미치는지에 대한 연구는 거의 이루어지지 못하였다.

만족, 신뢰, 몰입 둥은 구체적 속성에 의한 전반적 평가를 의미하고, 당사자들간의 관계의 질을 구성하는 개념이다. 그리고 몰입은 신뢰보다 좀 더 많은 시간을 필요로 하는 관계설명요인이다(Dwyer, Schurr and Oh 1987). 하지만 전반적 만족과 신뢰, 전반적 만족과 몰입간의 관계에 대한 연구는 찾아보기 어렵다.

기존의 다양한 연구에서 기업에 대한 전반적인 만족, 지각된 서비스의 품질 및 지각된 가치와 같은 전반적인 평가들은 상호간의 후광효과(Crosby and Stephens 1987)나 다중공선성(Rust, Zahorik, and Keiningham 1995) 등을 내포하고 서로 강한 통계적 관계를 갖고 있기 때문에 호환성이 있는 개념들로 이해되었다.

후광효과는 인지과정과 기억처리과정의 산물이다. 전반적인 평가는 많은 경험과 지각을 종합한 것이라는 것을 평가 기억(evaluative memory)에서 확인할 수 있다. 이러한 전반적인 평가는 다른 추론으로부터 구성된 추론 또는 다른 아이디어로부터 형성된 아이디어인 상위 정보의 통합체(high order syntheses of information)이다(Carlston 1980). 전반적인 평가는 동일한 매개 태도(intermediate attitudes)에 의해 영향을 받기 때문에 후광효과가 나타날 것으로 예상된다. 전반적인 만족과 몰입은 강한 퉁계적 관계를 동일한 매개태도에 의해서 형성할 수도 있다. 따라서, 요소별 만족에 의해서 전반적 만족과 몰입이 영향을 받는다면 요소별 영향정도를 파악하는 것이 중요하게 된다

Ostrom과 Iacobucci(1995)는 정보처리이론보다는 경제원리에 더욱 기반을 두었다지만 연구를 통하여 이와 유사한 결론을 제시하고 있다. 전반적인 만족평가와 지각된 가치, 그리고 구매가능성간의 후광효과를 제거하기 위해, 각각의 대상자가 단지 하나의 전반적인 평가를 하는 집단내 실헙설계(between-subjects experimental design)를 이용하였다. 그들은 가격과 질, 친숙성, 그리고 고객지향성에 대한 속성수준을 조작하고, 모든 속성이 전반적인 평가 정보에 영향을 미쳤지만, 속성의 영향력은 요구된 전반적인 평가유형에 따라 달라졌다고 설명하였다. 즉, 전반적 만족, 지각된 가치, 구매가능성 별로 속성들의 영향력은 달랐다. 이러한 관점에서 전반적 만족, 신뢰 몰입에 대한 요소별 만족들의 영향력을 검토할 필요가 있다. 그리고 구성개념들간의 내용타당성을 밀도있게 탐색할 필요가 있으며 전반적 만족과 신뢰, 전반적 만족과 몰입의 관계는 향후의 연구에서 다루고자 한다.

본 연구에서 신뢰는 기업이 제공한 서비스의 품질이나 신뢰성에 대한 소비자의 확신으로 정의한다. 전반적인 만족과 유사하게 본 연구에서는 기업이 제공한 서비스의 질에 대한 신뢰는 서비스 경험의 주요 요인에 대한 태도에 의해 영향올 받을 것으로 예상한다.

몰입은 소비자가 기업에 대하여 갖는 심리적 귀속감, 충성도, 미래 부에 대한 관심, 기업과의 심리적 일체감(identification), 기업에 대하여 갖는 자신감으로 정의한다.

Bhattacharya, Rao and Glynn(1995)은 박물관과 박물관 직원의 동일화경향에 대한 요인만족평가의 효과를 설명하였다. 그들의 연구에 있어서, 개별요인들은 영구 소장품(permanent collection), 순회 전시(traveling exhibition), 톡별 행사, 선물코너 둥 이었다.

따라서 전반적 만족과 유사하게 신뢰와 몰입도 전반적인 평가에 해당하기 때문에 요인별 만족의 영향을 받을 것으로 예상된다.

이러한 이론적 배경을 바탕으로 하여 본 연구에서는 높은 관계지향성을 가진 소비자의 경우에, 신뢰와 믈입은 심야전력서비스의 전반적 만족에 영향을 미치는 요인들 즉, 요금제도, 서비스맨과 제품 그리고 대리점에 대한 긍정적 만족에 의해 영향을 받을 것으로 예상되며 
이를 바탕으로 하여 다음 가설 2 와 3 을 설정하였다.

가설 2 : 심야전력서비스구성요인에 대한 만족(심야전력요금제도 만족, 서비스맨에 만족, 심야전력제품 만족, 대리점에 대한 만족)은 기업에 대한 물입에 긍정적인 영향을 미칠 것이다.

가설 3 : 심야전력서비스구성요인에 대한 만족(심야전력요금제도 만족, 서비스맨에 만족, 심야전력제품 만족, 대리점에 대한 만족)은 기업에 대한 신뢰에 긍정적인 영향을 미칠 것이다.

Morgan and Hunt(1994)의 신뢰와 몰입에 대한 연구에서는 몰입의 전 단계로서 신뢰를 고려하고 있다. 또한 Spekman(1988)은 신뢰는 관계적 교환에 있어 너무 중요하기 때문에, 신뢰가 전략적 파트너읩의 시금석이라는 것을 증명하였다. 신뢰에 의존한 관계는 매우 가치가 있기 때문에 당사자들은 그들 자신이 그러한 관계에 몰입되기를 원하는 것이다(Hrebiniak 1974).

사실 몰입이 취약성을 수반하기 때문에 당사자들은 오로지 신뢰성 있는 파트너만을 추구한다. 사회적 교환 이론은 이러한 인과적 관계를 일반화된 상호주의의 원리로써 설명하고 있는데, 그것은 잘못된 신뢰가 붕기를 유발하고 결과적으로 관계에 있어서 몰입을 감소시키며, 거래를 좀더 직접적이고 단기적인 교환으로 이동시킨다(McDonald 1981). 그러므로 신뢰가 관계몰입에 있어 주요한 결정요인이라고 본다. 우리의 가설을 확중하는 젓으로 Moorman, Zaltman, Deshpande(1992)은 마케팅 조사 이용자들의 연구 조사 제공자들에 대한 신뢰는 리서치 관계에 대한 이용자의 몰입에 매우 영향을 준다는 사실을 발견하였다. 한편 Morgan과 Hunt(1994)는 몰입은 이탈성향과 부정적 관계가 있음을 검중하였다. 따라서 재구매의도와 긍정적 관계가 있음을 가정할 수 있으며, 충성도와 공정성 그리고 배려성으로 설명되는 신뢰수준도 재구매의도에 긍정적 관계가 있음을 가정한다. 재구매개념은 계속적 관계를 가정하고 있기 때문에 몰입과 신뢰를 가정하지 않고 재구매의도를 설명하는 것은 의미가 없다. 이를 바탕으로 하여 다음 가설 $4,5,6$ 을 설정하였다.

가설 4 : 심야전력제품기업에 대한 신뢰는 심야전력제품기업에 대한 률입에 긍정적인 영향을 미칠 것이다.

가설 5 : 심야전력제품기업에 대한 신뢰는 재구매의도에 궁정적 영향을 미칠 것이다.

가설 6 : 심야전력재품기업에 대한 몰입은 재구매의도에 궁정적 영향을 미칠 것이다.

\section{3. 구전의도와 재구매의도}

한편, 전반적인 만족의 결과변수로는 김재일, 이유재 및 김주영(1996)이 세운 모형에서와 같이 구전과 재구매의도률 채택하였으며 전반적인 만족이 구전의도와 재구매의도에 긍정적인 영향을 미칠 것으로 예상할 수 있다. 이률 바탕으로 하여 다음 가설 7 과 8 을 설정하였다.

가설 7 : 심야전력제품기업에 대한 전반적인 만족은 심야전력제품기업에 대한 구전의도에 긍정적 영향을 미칠 것이다. 
가설 8 : 심야전력재품기업에 대한 전반적인 만족은 심야전력제품기업에 대한 재구매의도에 긍정적 영향을 미칠 것이다.

위에서 제시한 가설을 바탕으로 하여 본 연구에서 검중하고자 하는 연구모형은 다음 <그림 1>에 나타나 있다.

<그림 1> 본 연구의 연구모형

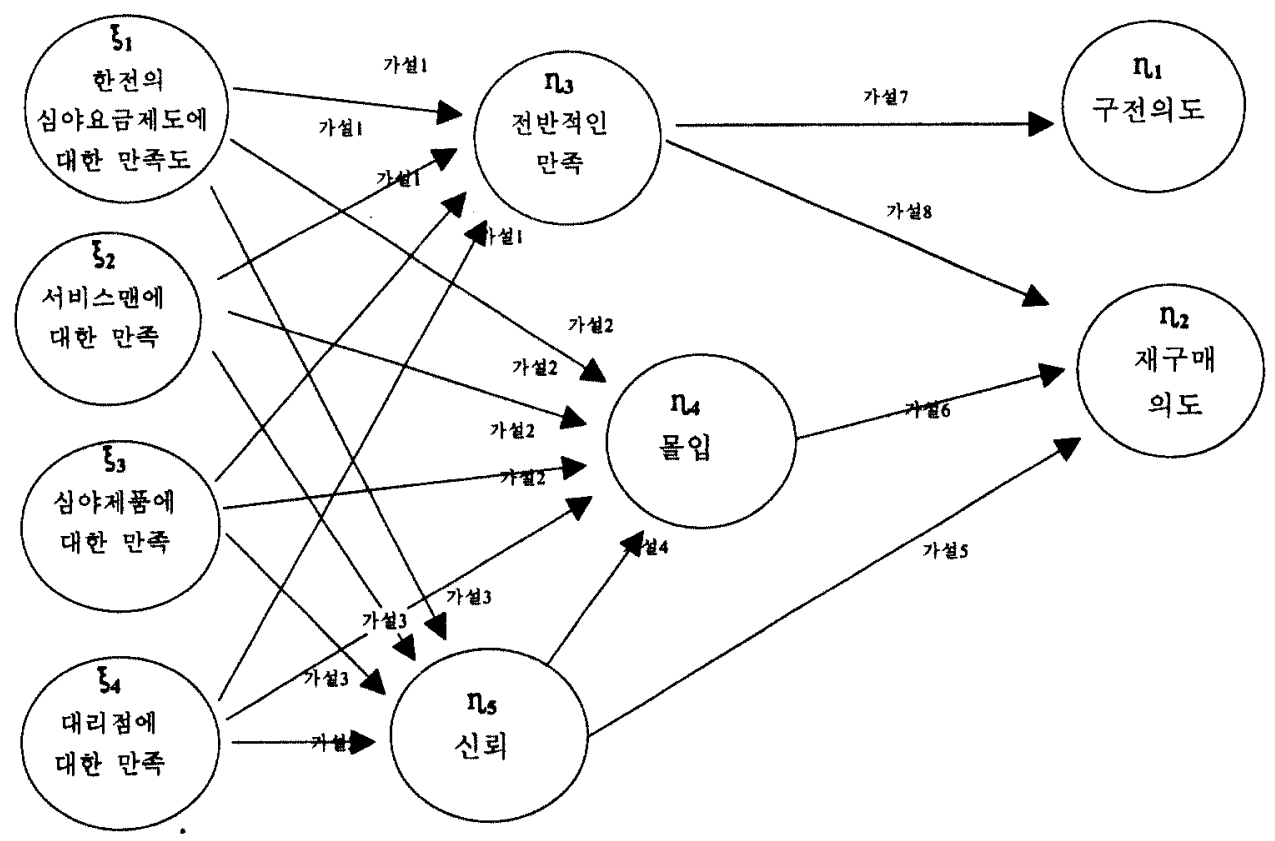

\section{4. 실중분석}

\section{1. 변수의 측정}

\subsection{1. 전반적 만족과 몰입 및 신뢰에 대한 측정}

고객의 전반적인 만족은 대리점 취급 제품의 전반적인 질 및 한전의 심야전력요금제도에 대한 전반적 만족 등 2 개 항목으로 측정하였다. 세부요인별 만족측정에서 서비스맨에 대한 만족은 대리점 직원의 서비스, 태도, 친절 및 고객의 고장수리요구에 대한 서비스맨의 태도 등 2 개 항목으로 측정되었다. 심야전력요금제도의 만족도는 일반적인 심야전력요금 수준, 전기품질대비 요금수준, 사용시간에 따른 요금수준의 적정성 둥 총 3 개 항목을, 심야전력제품의 만족도는 품질보중기간, 고장정도, 디자인, 설치용이성 둥 충 4개 항목을, 판매대리점 만족은 대리점서비스에 대한 만족, 대리점시설에 대한 만족 둥 총 3 개 항목을 측정하여 이용하였다. 
몰입수준은 Mathieu와 Zajac(1990)의 개념을 이용하여 감정적 측면에서 심야전력제품에 대한 매력, 그리고 계산적 측면에서 생활에서 의미 및 도움 둥 3 개 항목으로 측정하였다. 그리고 신뢰에 대해서는 Podsakoff et al.(1990)의 개념을 이용하여 심야제품 판매대리점의 업무처리에 대한 신뢰, 서비스의 객관성과 공정성, 그리고 제품에 대한 신뢰정도, 고객입장의 고려정도 둥 충 4 개 항목으로 측정하였다.

각 항목에 대한 측정 방법은 7점 척도를 사용하였다.

\subsection{2. 구전 및 재구매 의도측정}

구전의도는 심야전력상품을 사용하고 있는 고객이 사용한 경헙을 바탕으로 동제품을 타인에게 자랑하는 정도와 긍정적으로 이야기하는 정도 둥 2 개 항목으로 측정하였으며, 재구매의도는 향후 고객의 계속적인 재구매 의사와 타인에게 추천 및 권유 의향 정도 등 2 개 항목으로 측정하였다. 측정방법 역시 7점 척도를 사용하였다.

\section{2. 자료의 수집과 처리}

각 구성개녑에 대한 측정항목을 7점 척도로 설문화하고, 조사 대상은 고객과 기업의 관계지향성이 높은 경우에 국한되어야 하기 때문에 5 년 이상 심야전력제품을 사용한 고객 중에서 장기간 사용되면서 애프터서비스가 필요한 심야전력상품 중 가장 일반적으로 보급되어 있는 심야전력 전기온돌, 전기보일러, 전기온수기 둥을 사용하는 고객올 조사 대상으로 하였다. 조사방법은 $\mathrm{J}$ 지역 한전 검침원 45 명이 자기 담당지역 정기 검침일에 해당 고객을 면담하여 설문하였다. 설문지는 총 200 부를 배포하여 184 부가 회수되었으며 이중에서 불성실하게 웅답한 11 명을 제외하고 최종적으로 173 부가 자료처리에 이용되었다. 가설검중을 위한 자료처리는 구조방정식 접근방법을 이용하였다.

\section{3. 구성개념의 신뢰도와 판별타당성 검증}

<그립 1>에 제시된 구조적 모델을 검중하기 위하여 Lisrel 8.14 (Joreskog and Sorbom, 1993)를 이용하였다.

\subsection{1. 구성개념의 요인분석}

계량분석의 첫번째 단계로서 베리멕스(Varimax)회전법을 사용한 주성분 요인분석(the principal components factor analysis)을 실시하였다. 이 요인분석을 퉁하여 전반적 만족도, 서비스맨에 대한 만족도, 심야전략요금제도 및 전기품질에 대한 만족도, 심야전력제품에 대한 만족도, 판매대리점에 대한 만족도, 심야전력제품에 대한 몰입, 심야전력제품에 대한 신뢰도, 구전의도, 재구매 의도의 각 변수간 구성개념의 구조릅 파악하였다. 그리고 추출된 각 요인의 측정신뢰성을 검중하기 위하여 크론바 알파(Cronbach's alpha)값을 구하였다. 분석결과는 다음 <표 1>에서 보는 바와 같다. 
<표 1> 변수간의 수렵타당성과 신뢰도 검중

\begin{tabular}{|c|c|c|c|c|c|c|c|c|c|c|}
\hline 요인 & 측정항목 & 요인 1 & 요인2 & 요인3 & 요인4 & 쇼인5 & 요인6 & 요인7 & 요인8 & 요인9 \\
\hline $\begin{array}{l}\text { OVER } \\
\text {-SATIS }\end{array}$ & $\begin{array}{c}\text { 심야전력에 대한 전반적 만족 } \\
\text { 심야전력제품에 대한 생각 }\end{array}$ & $\begin{array}{l}.547 \\
.473\end{array}$ & & & & & & & & \\
\hline $\begin{array}{c}\text { SER } \\
\text {-SATIS } \\
\end{array}$ & $\begin{array}{l}\text { 판매대리점 직원서비스 } \\
\text { 판매대리점 고객웅대태도 }\end{array}$ & & $\begin{array}{l}.570 \\
.591 \\
\end{array}$ & & & & & & & \\
\hline $\begin{array}{l}\text { QUAL } \\
\text {-SATIS }\end{array}$ & $\begin{array}{c}\text { 일반적 요큼수준 } \\
\text { 전기품질대비 요금수준 } \\
\text { 사용시간에 따른 } \\
\text { 요금수준적정성 }\end{array}$ & & & $\begin{array}{l}.777 \\
.775 \\
.660\end{array}$ & & & & & & \\
\hline $\begin{array}{l}\text { PRO } \\
\text {-SATIS }\end{array}$ & $\begin{array}{c}\text { 품질보중기간 } \\
\text { 심야전력제품의 고장정도 } \\
\text { 심야전력제품의 디자인 } \\
\text { 심야전력제품의 설치용이성 }\end{array}$ & & & & $\begin{array}{l}.471 \\
.420 \\
.682 \\
.732 \\
\end{array}$ & & & & & \\
\hline $\begin{array}{l}\text { STO } \\
\text {-SATIS }\end{array}$ & $\begin{array}{l}\text { 판매대리점에 대한 생각 } \\
\text { 판매대리점에 대한 만족 } \\
\text { 판매대리점의 시설정도 }\end{array}$ & & & & & $\begin{array}{l}.720 \\
.792 \\
.761 \\
\end{array}$ & & & & \\
\hline $\begin{array}{l}\text { COMMIT } \\
\text {-MENT }\end{array}$ & $\begin{array}{l}\text { 심야전력제품에 대한 매력 } \\
\text { 심야전력제품이 생휠에 주는 의미 } \\
\text { 심야전력제품이 생활에 보텀정도 }\end{array}$ & & & & & & $\begin{array}{l}.594 \\
.667 \\
.721\end{array}$ & & & \\
\hline TRUST & $\begin{array}{c}\text { 업무처리의 신뢰성 } \\
\text { 서비스의 객관성과 공정성 } \\
\text { 심야전력제품에 대한 믿음 } \\
\text { 고객입장의 고려정도 }\end{array}$ & & & & & & & $\begin{array}{l}.612 \\
.500 \\
.457 \\
.720\end{array}$ & & \\
\hline $\begin{array}{l}\text { INTEN } \\
\text {-TION }\end{array}$ & $\begin{array}{c}\text { 타인에 게 자랑하는 정도 } \\
\text { 타인에게 줗다고 이야기하는 정도 }\end{array}$ & & & & & & & & $\begin{array}{l}.734 \\
.777\end{array}$ & \\
\hline $\begin{array}{c}\text { REPUR } \\
\text {-CHASE }\end{array}$ & $\begin{array}{c}\text { 재구매의도 } \\
\text { 타인에 게 추천이나 권유의도 }\end{array}$ & & & & & & & & & $\begin{array}{l}.791 \\
.74\end{array}$ \\
\hline & 아이겐값 & 6.72 & 6.14 & 4.78 & 2.80 & 1.78 & 1.75 & 1.62 & 1.56 & 1.40 \\
\hline & 분산의 설명력(\%) & 17.2 & 15.8 & 12.3 & 7.2 & 4.9 & 4.5 & 4.2 & 4.0 & 3.6 \\
\hline & 신뢰성계수( alpha ) & .67 & .88 & .83 & .86 & .89 & .83 & .86 & .89 & .81 \\
\hline
\end{tabular}

주 : OVERSATIS : 전반적 만족도, SERSATIS : 서비스맨에 대한 만족도, QUALSATIS : 심야전력요금제도 및 전기품질에 대한 만족도, PROSATIS : 심야전력제품에 대한 만족도, STOSATIS : 판매대리점에 대한 만족도, COMMITMENT : 심야전력제품에 대한 몰입, TRUST :심야전력재품에 대한 신뢰도, INTENTION : 구전의도, REPURCHASE : 재구매의도

표에서 나타난 바와 같이 9 개의 요인은 총분산의 $73.7 \%$ 률 설명하고 있으며 각 요인의 신뢰성계수(alpha )는 0.67 에서 0.89 사이로 나타나서 채택할 만한 수준을 보였다.

\subsection{2. 판별타당성 검중}

본 연구에서 사용된 전반적 만족도, 서비스맨에 대한 만족도, 심야전력요금제도 및 전기품질에 대한 만족도, 심야전력제품에 대한 만족도, 판매대리점에 대한 만족도, 심야전력제품에 대한 몰입, 심야전력제품에 대한 신뢰도, 구전의도, 재구매의도에 대한 
구성개념간의 판별 타당성을 검토하기 위하여, Lisrel기법에 의한 확인적 요인분석(Confirmatory Factor Analysis)을 실시하고 구성개념간의 상관관계분석울 실시하였다.

<표 2>의 구성개념간의 상관관계표에서 보는 바와 같이 2 배의 표준오차에 상관관계를 더해도 $95 \%$ 의 신뢰구간에서 동일시되는 구성개념을 찾을 수 없다. 따라서 구성개념간의 판별타당성이 존재함을 알 수 있다(이유재, Bagozzi 2000).

<표 2> 구성개념간의 상관관계와 표준오차

\begin{tabular}{|c|c|c|c|c|c|c|c|c|c|}
\hline & $\begin{array}{c}\text { SER } \\
\text {-SATIS }\end{array}$ & $\begin{array}{l}\text { QUAL } \\
\text {-SATIS }\end{array}$ & $\begin{array}{c}\text { PRO } \\
\text {-SATIS }\end{array}$ & $\begin{array}{c}\text { STO } \\
\text {-SATIS }\end{array}$ & $\begin{array}{l}\text { OVER } \\
\text {-SATIS }\end{array}$ & $\begin{array}{l}\text { COMMIT } \\
\text {-MENT }\end{array}$ & TRUST & $\begin{array}{l}\text { INTEN } \\
\text {-TION }\end{array}$ & $\begin{array}{l}\text { REPUR } \\
\text {-CHASE }\end{array}$ \\
\hline $\begin{array}{c}\text { SER } \\
\text {-SATIS }\end{array}$ & 1.00 & & & & & & & & \\
\hline $\begin{array}{c}\text { QUAL } \\
\text {-SATIS }\end{array}$ & $\begin{array}{c}.38 \\
(0.11)\end{array}$ & 1.00 & & & & & & & \\
\hline $\begin{array}{l}\text { PRO } \\
\text {-SATIS }\end{array}$ & $\begin{array}{c}.78 \\
(.08)\end{array}$ & $\begin{array}{c}.46 \\
(0.11)\end{array}$ & 1.00 & & & & & & \\
\hline $\begin{array}{c}\text { STO } \\
\text {-SATIS }\end{array}$ & $\begin{array}{c}.78 \\
(0.06)\end{array}$ & $\begin{array}{c}.38 \\
(0.10)\end{array}$ & $\begin{array}{c}.81 \\
(0.06)\end{array}$ & 1.00 & & & & & \\
\hline $\begin{array}{l}\text { OVER } \\
\text {-SATIS }\end{array}$ & $\begin{array}{c}.79 \\
(0.09)\end{array}$ & $\begin{array}{c}.64 \\
(0.10)\end{array}$ & $\begin{array}{c}.84 \\
(0.06)\end{array}$ & $\begin{array}{c}.78 \\
(0.08)\end{array}$ & 1.00 & & & & \\
\hline $\begin{array}{l}\text { COMMIT } \\
\text {-MENT }\end{array}$ & $\begin{array}{c}.77 \\
(0.07)\end{array}$ & $\begin{array}{c}.56 \\
(0.09)\end{array}$ & $\begin{array}{c}.83 \\
(0.07)\end{array}$ & $\begin{array}{c}.70 \\
(0.07)\end{array}$ & $\begin{array}{c}.81 \\
(0.07)\end{array}$ & 1.00 & & & \\
\hline TRUST & $\begin{array}{c}.77 \\
(0.07)\end{array}$ & $\begin{array}{c}.42 \\
(0.10)\end{array}$ & $\begin{array}{c}.83 \\
(0.05)\end{array}$ & $\begin{array}{c}.90 \\
(0.04)\end{array}$ & $\begin{array}{c}.84 \\
(0.07)\end{array}$ & $\begin{array}{c}.88 \\
(0.05)\end{array}$ & 1.00 & & \\
\hline $\begin{array}{l}\text { INTEN } \\
\text {-TION }\end{array}$ & $\begin{array}{c}.60 \\
(0.08)\end{array}$ & $\begin{array}{c}.44 \\
(0.10)\end{array}$ & $\begin{array}{c}.68 \\
(0.08)\end{array}$ & $\begin{array}{c}.67 \\
(0.07)\end{array}$ & $\begin{array}{c}.74 \\
(0.08)\end{array}$ & $\begin{array}{c}.82 \\
(0.05)\end{array}$ & $\begin{array}{c}.83 \\
(0.04)\end{array}$ & 1.00 & \\
\hline \begin{tabular}{|c|} 
REPUR \\
-CHASE
\end{tabular} & $\begin{array}{c}.65 \\
(0.09)\end{array}$ & $\begin{array}{c}.58 \\
(0.09)\end{array}$ & $\begin{array}{c}.57 \\
(0.10)\end{array}$ & $\begin{array}{c}.59 \\
(0.10)\end{array}$ & $\begin{array}{c}.59 \\
(0.08)\end{array}$ & $\begin{array}{c}.84 \\
(0.04)\end{array}$ & $\begin{array}{c}.85 \\
(0.05)\end{array}$ & $\begin{array}{c}.81 \\
(0.05)\end{array}$ & 1.00 \\
\hline
\end{tabular}

주 : OVERSATIS : 전반적 만족도, SERSATIS : 서비스맨에 대한 만족도, QUALSATIS : 심야전력요금제도 및 전기품질에 대한 만족도, PROSATIS : 심야전력제품에 대한 만족도, STOSATIS : 판매대리점에 대한 만 족도, COMMITMENT :심야전력제품에 대한 몰입, TRUST :심야전력제품에 대한 신뢰도, INTENTION: 구전 의도, REPURCHASE : 재구매의도

* ( ) 안의 숫자는 표준오차임

\section{4. 연구가설의 검중}

\subsection{1. 연구모형의 검중}

본 연구에서 고객의 구전과 재구매 의도에 대한 만족, 신뢰, 몰입의 매개적 역할올 검중하기 위하여 공분산 구조분석을 실시해 모형의 적합도를 확인하고, 모형상의 모수들올 동시에 추정하였다. 모수추정법은 최우추정법(maximum likelihood method)을 이용하였다. 모형상 모수들에 대한 Lisrel의 추정결과는 <표 3>과 같다. 
<표 3> 연구모형의 모수에 대한 LISREL추정치

\begin{tabular}{|c|c|c|c|c|c|c|c|}
\hline \multicolumn{4}{|c|}{ 구조모형(structural model) } & \multicolumn{4}{|c|}{ 측정모형(measurement model) } \\
\hline 모수 & $\begin{array}{l}\text { LISERL } \\
\text { 추정치 }\end{array}$ & 표준오차 & t값 & 모수 & $\begin{array}{c}\text { LISREL } \\
\text { 추정치 }\end{array}$ & 표준오차 & t값 \\
\hline$y_{31}$ & 0.22 & 0.041 & 5.23 & $\lambda_{y 11}$ & 1.21 & 0.087 & 13.89 \\
\hline$\gamma_{41}$ & 0.30 & 0.082 & 3.68 & $\lambda_{y 21}$ & 1.06 & 0.057 & 18.54 \\
\hline 851 & $\mathrm{NS}^{*}$ & - & - & $\lambda_{y 32}$ & 0.92 & 0.14 & 6.47 \\
\hline $8_{32}$ & 0.24 & 0.066 & 3.67 & $\lambda_{y 42}$ & 0.98 & 0.10 & 9.48 \\
\hline$\gamma_{42}$ & 0.41 & 0.11 & 3.58 & $\lambda_{y 53}$ & 0.76 & 0.16 & 8.61 \\
\hline $8_{32}$ & $\mathrm{NS}^{*}$ & - & - & $\lambda_{y 63}$ & 0.68 & 0.10 & 6.64 \\
\hline 833 & 0.44 & 0.084 & 5.26 & $\lambda_{y 74}$ & 0.84 & 0.19 & 4.06 \\
\hline $8_{43}$ & $\mathrm{NS}^{*}$ & - & - & $\lambda_{y 84}$ & 0.96 & 0.11 & 8.98 \\
\hline$\gamma_{53}$ & 0.26 & 0.088 & 2.96 & $\Lambda_{y 94}$ & 0.95 & 0.11 & 8.66 \\
\hline$x_{34}$ & 0.15 & 0.079 & 2.95 & $\lambda_{y 105}$ & 0.80 & 0.040 & 19.94 \\
\hline$\gamma_{44}$ & $\mathrm{NS}^{*}$ & - & - & $\lambda_{y 115}$ & 0.91 & 0.11 & 8.21 \\
\hline 854 & 0.39 & 0.074 & 5.26 & $\lambda_{y 125}$ & 0.92 & 0.099 & 9.35 \\
\hline$\beta_{13}$ & 0.82 & 0.12 & 7.28 & $\lambda_{y 13 s}$ & 0.97 & 0.098 & 9.90 \\
\hline$\beta_{23}$ & 3.70 & 1.42 & 2.60 & $\lambda_{x 11}$ & 0.66 & 0.095 & 6.88 \\
\hline$\beta_{24}$ & 4.17 & 0.90 & 4.66 & $\lambda_{x 21}$ & 0.52 & 0.099 & 5.28 \\
\hline$\beta_{25}$ & $\mathrm{NS}^{*}$ & - & - & $\lambda_{\times 31}$ & 0.96 & 0.099 & 9.79 \\
\hline \multirow[t]{2}{*}{$\beta_{45}$} & 1.96 & 0.29 & 6.69 & $\lambda_{x 42}$ & 0.92 & 0.095 & 9.69 \\
\hline & & & & $\lambda_{x 52}$ & 0.89 & 0.11 & 8.28 \\
\hline \multirow{2}{*}{\multicolumn{4}{|c|}{$R^{2}\left(n_{1}\right)=0.73$}} & $\lambda_{\mathrm{x} 63}$ & 0.71 & 0.10 & 6.82 \\
\hline & & & & $\lambda_{x 73}$ & 0.70 & 0.095 & 7.36 \\
\hline \multicolumn{4}{|c|}{$R^{2}\left(n_{2}\right)=0.60$} & $\lambda_{x 83}$ & 0.80 & 0.10 & 7.98 \\
\hline \multicolumn{4}{|c|}{$R^{2}\left(n_{3}\right)=0.82$} & $\lambda_{x 93}$ & 0.65 & 0.12 & 5.38 \\
\hline \multicolumn{4}{|c|}{$R^{2}\left(n_{4}\right)=0.94$} & $\lambda_{\times 104}$ & 0.86 & 0.075 & 11.38 \\
\hline \multirow{2}{*}{\multicolumn{4}{|c|}{$\mathrm{R}^{2}\left(n_{5}\right)=0.90$}} & $\lambda_{x 114}$ & 0.97 & 0.080 & 12.06 \\
\hline & & & & $\lambda_{\mathrm{x} 124}$ & 0.93 & 0.089 & 10.43 \\
\hline \multicolumn{8}{|c|}{ CHI-SQUARE WITH 325 DEGREES OF FREEDOM $=307.80(P=0.0058)$} \\
\hline \multicolumn{8}{|c|}{ ROOT MEAN SQUARE RESIDUAL (RMR) $=0.068$} \\
\hline \multicolumn{8}{|c|}{ GOODNESS OF FIT INDEX (GFI) $=0.92$} \\
\hline \multicolumn{8}{|c|}{ ADJUSTED GOODNESS OF FIT INDEX (AGFI) $=0.87$} \\
\hline
\end{tabular}

$\mathrm{NS}^{*}$ : non significant

결과적으로 전체적인 모형의 적합도 평가치는 <표 3>에 제시된 바와 같이 기초부합지수 $(\mathrm{GFI})=0.92$, 수정부합지수 $(\mathrm{AGFI})=0.87$, 표준화된 원소평균자숭잔차 $(\mathrm{RMR})=$ 0.068 이었다.

4.4.2. 연구가설의 검증

본 연구에서 설정한 가설들의 검정 결과를 요약하면 다음 <표 $4>$ 와 <그림 $2>$ 와 같다. 
<표 4> 가설겁중의 요약

\begin{tabular}{|c|c|c|c|c|c|}
\hline 가설 & 가설경로 및 방향 & $\begin{array}{l}\text { 졍로 } \\
\text { 명칭 }\end{array}$ & $\begin{array}{l}\text { 경로 } \\
\text { 계수 }\end{array}$ & $\begin{array}{l}\text { 채택 } \\
\text { 여부 }\end{array}$ & 유의수준 \\
\hline \multirow{4}{*}{ 가설 1(+) } & QUALSATIS( $\left(\xi_{1}\right) \rightarrow \operatorname{OVERSATIS}\left(n_{3}\right)$ & $\gamma_{31}$ & 0.22 & 0 & $\mathrm{p}<0.05$ \\
\hline & SERSATIS $\left(3_{2}\right) \rightarrow$ OVERSATIS $\left(n_{3}\right)$ & 832 & 0.24 & 0 & $\mathrm{p}<0.05$ \\
\hline & $\operatorname{PROSATIS}\left(\xi_{3}\right) \rightarrow \operatorname{OVERSATIS}\left(\mathrm{n}_{3}\right)$ & 833 & 0.44 & 0 & $\mathrm{p}<0.05$ \\
\hline & STOSATIS $\left(\xi_{4}\right) \rightarrow$ OVERSATIS $\left(\mathbb{n}_{3}\right)$ & 834 & 0.15 & 0 & $\mathrm{p}<0.05$ \\
\hline \multirow{4}{*}{ 가설 2(+) } & QUALSATIS $(\xi, 1) \rightarrow \operatorname{COMMITMENT}\left(\pi_{4}\right)$ & $\gamma_{41}$ & 0.30 & 0 & $\mathrm{p}<0.05$ \\
\hline & $\operatorname{SERSATIS}\left(3_{2}\right) \rightarrow \operatorname{COMMITMENT}\left(n_{4}\right)$ & 842 & 0.41 & 0 & $\mathrm{p}<0.05$ \\
\hline & PROSATIS $\left(\xi_{3}\right) \rightarrow \operatorname{COMMITMENT}\left(\mathrm{n}_{4}\right)$ & 843 & - & $x$ & $N . s^{*}(a=0.05)$ \\
\hline & $\operatorname{STOSATIS}\left(\xi_{4}\right) \rightarrow \operatorname{COMMITMENT}\left(n_{4}\right)$ & $x_{44}$ & - & $x$ & $N . S^{*}(a=0.05)$ \\
\hline \multirow{4}{*}{ 가설3(+) } & QUALSATIS $\left(\xi_{1}\right) \rightarrow \operatorname{TRUST}\left(n_{5}\right)$ & $\mathrm{Y} s 1$ & - & $x$ & $N . S^{*}(a=0.05)$ \\
\hline & $\operatorname{SERSATIS}\left(3_{2}\right) \rightarrow \operatorname{TRUST}\left(n_{3}\right)$ & $\mathrm{X}_{32}$ & - & $x$ & N.S. $(a=0.05)$ \\
\hline & $\operatorname{PROSATIS}\left(\xi_{3}\right) \rightarrow \operatorname{TRUST}\left(\pi_{s}\right)$ & 853 & 0.26 & 0 & $p<0.05$ \\
\hline & $\operatorname{STOSATIS}\left(\xi_{4}\right) \rightarrow \operatorname{TRUST}\left(\eta_{3}\right)$ & $\gamma_{s 4}$ & 0.39 & 0 & $p<0.05$ \\
\hline 가설4(+) & $\operatorname{TRUST}\left(n_{5}\right) \rightarrow \operatorname{COMMITMENT}\left(n_{4}\right)$ & $\beta_{45}$ & 1.96 & 0 & $p<0.05$ \\
\hline 가설 5(+) & TRUST(n s) $\rightarrow$ REPURCHASE $\left(n_{2}\right)$ & $\beta_{25}$ & - & $x$ & $N . s^{*}(\mathfrak{a}=0.05)$ \\
\hline 가설6(+) & $\operatorname{COMMITMENT}\left(\mathfrak{n}_{4}\right) \rightarrow \operatorname{REPURCHASE}\left(\mathfrak{n}_{2}\right)$ & $\beta_{24}$ & 4.17 & 0 & $\mathrm{p}<0.05$ \\
\hline 가설7(+) & OVERSATIS $\left(n_{3}\right) \rightarrow$ INTENTION $\left(n_{1}\right)$ & $\beta_{13}$ & 0.82 & 0 & $\mathrm{p}<0.05$ \\
\hline 가설 8(+) & OVERSATIS $\left(\mathrm{n}_{3}\right) \rightarrow \operatorname{REPURCHASE}\left(\mathrm{n}_{2}\right)$ & $\beta_{23}$ & 3.70 & 0 & $p<0.05$ \\
\hline
\end{tabular}

N.S* : non significant 주 : OVERSATIS : 전반적 만족도, SERSATIS : 서비스맨에 대한 만족도, QUALSATIS : 심야전력요 금제도 및 전기품질에 대한 만족도, PROSATIS : 심야전력제품에 대한 만족도, STOSATIS : 판매대 리점에 대한 만족도, COMMITMENT :심야전력제품에 대한 뭅입, TRUST :심야전력제품에 대한 신 뢰도, INTENTION : 구전의도, REPURCHASE : 재구매의도 


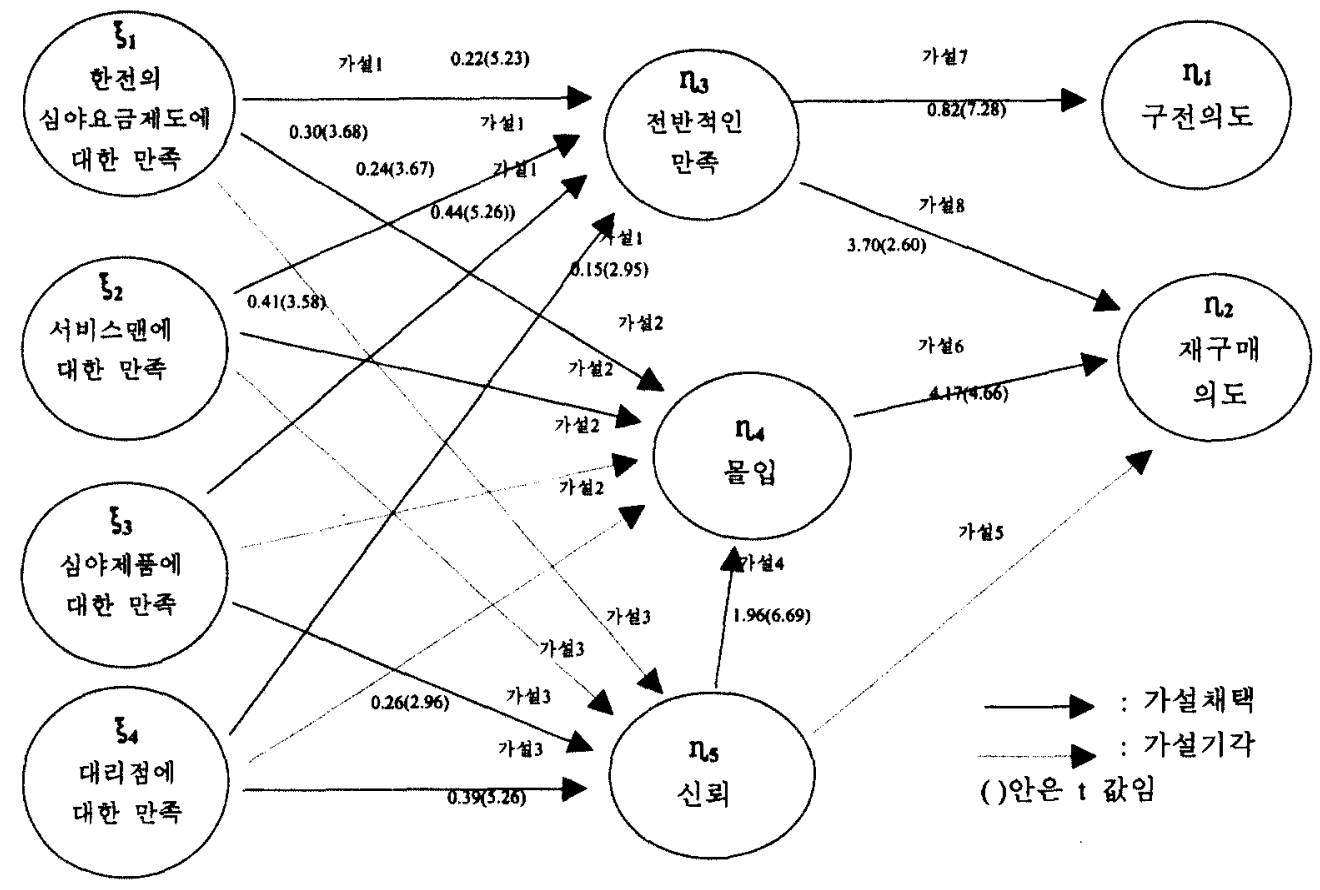

위의 <표 4>와 <그림 2>에서 나타난 바와 같이 요인별 만족(심야전력요금 제도에 대한 만족, 서비스맨에 대한 만족, 심야전력제품에 대한 만족, 대리점에 대한 만족)과 전반적인 만족간의 정의 관계를 가정한 가설 1 의 경우에는 심야전력요금제도에 대한 만족, 서비스맨에 대한 만족, 심야전력 제품에 대한 만족, 대리점에 대한 만족의 모든 요소가 전반적인 만족과 정의 관계를 나타내고 있다. 이는 전반적인 만족이 한전의 심야전력요금제도, 서비스맨의 서비스정도, 심야제품의 품질 및 대리점시설 둥과 같은 다양한 ㅇ․소들로부터 영향을 받는다는 것을 알 수 있다.

요인별 만족(심야전력요금제도에 대한 만족, 서비스맨에 대한 만족, 심야전력제품에 대한 만족, 대리점에 대한 만족)과 기업에 대한 몰입간의 긍정적인 관계를 가정한 가설2의 경우에는 전반적인 만족의 경우와는 달리 네 개의 요소 중 심야전력요금제도에 대한 만족과 서비스맨에 대한 만족이 몰입과 정의 관계를 나타내고 있다. 이러한 결과는 기업에 대한 몰입요인은 한전의 심야전력요금제도와 서비스맨의 요인이 주 영향요인이라는 점을 보여주고 있다.

요인별 만족(심야전력요금제도에 대한 만족, 서비스맨에 대한 만족, 심야전력제품에 대한 만족, 대리점에 대한 만족)과 기업에 대한 신뢰간의 긍정적인 관계를 가정한 가설3의 경우에는 전반적인 만족이나 물입과는 달리 심야전력 제품에 대한 만족과 대리점 시설에 대한 만족이 기업의 신뢰와 정의 관계를 가지고 있는 것으로 나타나고 있다.

기업에 대한 신뢰와 기업에 대한 몰입간의 긍정적인 관계를 가정한 가설4의 경우에는 가설 검증결과 유의적인 정의 관계를 나타내고 있다. 이는 본 연구에서 핵심적인 부분으로 일반적으로 본 연구에서 다루고 있는 요소만족의 일부(심야전력제품에 대한 만족, 대리점에 
대한 만족) 요인들이 몰입에 직접 영향을 미치지 않고 신뢰에 영향을 미친 다음 다시 이러한 신뢰가 몰입에 영향을 미친다는 것을 알 수 있다. 즉 신뢰가 요인별 만족과 몰입사이의 매개적 역할을 하고 있다는 점을 보여주는 것이다.

신뢰와 재구매의도와의 정의 관계를 가정한 가설5의 경우에는 본 연구를 통하여 유의적인 관계가 나타나고 있지 않음으로써 이 가설은 기각한다. 그러나 몰입과 재구매의도와의 정의 관계를 가정한 가설 6 과 전반적인 만족과 구전의도 및 재구매의도와의 정의 관계를 가정한 가설 7 과 8 의 경우에는 유의적인 관계률 나타내고 있음으로써 이들 두 개의 가설을 채택한다.

\section{5. 결 론}

\section{1. 연구의 요약}

Fournier, Dobscha and Mick(1998)은 관계마케팅은 이론적으로는 아주 강력하지만 실행에 옮기는데 있어서는 문제가 있다고 하였다. 그들은 관계마케팅을 수행하려는 마케터들에 대하여 고객들이 기업과의 어떤 관계를 유지하려고 하는지에 대한 정확한 이해없이 고객과의 동반자관계를 추구하면서 관계마케팅을 수행하려는 마케터들을 아주 강도높게 비빤하고 있는데, 이는 기업이 기업에 대한 고객의 관계지향성을 무시한 채 모든 고객에게 관계마케텅을 수행하려 한다는 점울 근거로 하고 있다. 이와 관련하여 관계마케텅을 다루었던 Jackson(1985)은 그의 연구에서 기업은 거래적 마케팅과 관계적 마케팅을 모두 수행하여야 하는데, 그 이유는 고객들이 기업과의 관계에 있어서 힉일적이지 않고 거래적 관계로부터 관계적 관계까지의 연속적 관계의 다른 위치를 추구하고 있기 때문이라고 제시하고 있다. Anderson과 Narus(1991)도 이러한 입장을 지지하면서 동반자관계는 협동적 마케팅전략에 의해서 구축될 수 있을 뿐만 아니라 협력적인 관계를 지향하는 고객에 대해서 유효한 전략이라고 하였다. 또한 Berry(1995)는 그의 연구를 퉁하여 이러한 견해를 뒷받침하면서 서비스 조직들이 이들 두 가지 관점의 교환을 동시에 고려하는 마케팅전략의 수립과 실행이 필요하다고 하였다.

그런데 기존 연구들은 체계적 접근보다는 사례적 근거를 기초로 하고 있으며 또한 상대적으로 관계지향적 고객을 대상으로 한 실중연구는 미흡한 실정이다. 이러한 관계지향적 고객을 대상으로 한 관계마케팅에 대한 연구는 고객의 관계지향성 수준은 재구매의도와 같은 기업의 성장요인에 영향을 줄 수 있는 선행변수로 작용할 수 있기 때문에 관계지향성 수준에 따라 고객을 구분하고 톡히, 관계지향적 고객을 대상으로 하는 관계마케팅 연구가 필요하다. 재구매와 구전온 기업에 대한 고객의 가치이고 특히, 재구매는 지속적 관계의 성과내용이기 때문에 관계마케팅의 관점에서 검토되어야 할 펄요가 있다. 그런데, 관계지향적 고객은 지속적 재구매 현상으로 설명되며, 지속적 재구매는 기업과 고객간의 신뢰와 몰입수준을 선행요인으로 다루지 않는다면 설명변수에 문제가 있다. 따라서 본 연구는 관계지향적 고객의 재구매의도를 설명하기 위한 매개요인으로 전반적 만족과 합께 믈입과 신뢰개념을 도입하여 수행되었다.

이률 위해 장기적으로 5 년이상 거래관계를 맺고 있는 심야전력서비스이용자를 표본으로 
하여 실중연구률 수행하였다.

본 연구의 결과는 다음과 같다.

첫째, 전반적 만족은 요인별 만족과 구전의도 및 재구매의도에 매개적 역할을 하는 것으로 나타넜다. 그리고 관계적 교환관계에 있어서 고객의 서비스의 구체적 요인에 대한 만족과 재구매의도는 신뢰와 몰입수준에 의해 매개되며 또한, 몰입수준은 전반적인 만족보다 더 강하게 재구매의도에 영향을 미치는 것으로 나타났다.

둘째, 신뢰에 대한 영향요인과 몰입에 대한 영향요인이 다르게 나타났다. 즉, 몰입은 심야요금제도와 서비스맨에 대한 만족에 영향을 받지만 신뢰는 심야제품과 대리점 만족에 영향을 받는 것으로 나타넜다. 서비스맨에 대한 만족이 몰입에만 영향을 미치고, 또 제품요인과 대리점요인이 신뢰에만 영향을 미친다는 점에 유의할 필요가 있다. 즉, 서비스맨의 고객웅대태도가 감정적 요소로서 몰입에 영향을 미치며, 제품에 대한 인지적 평가와 대리점의 공정성과 객관성, 시설 둥의 인지적 평가가 신뢰에 영향을 미친다는 것이다.

신뢰와 몰입의 영향요인간에 차이가 나는 것은 Dwyer, Schurr and $\mathrm{Oh}(1987)$ 의 관계의 5 단계(인지, 탐색, 확장, 몰입, 해체) 모형에 의해서 설명이 가능하다고 본다. 단계의 이동은 당사자들이 서로를 보는 방법에서 중요한 전환을 요구하고 있다. 신뢰의 정직요소는 탐색단계에서 형성되고 자비성(benevolence) 요소는 확장단계 즉, 당사자들이 미래의 상호작용올 약속하기 위한 기대들을 형성하는 단계에 진입되어야 형성된다. 몰입단계는 구매자와 판매자간의 관계에서 성숙정도가 가장 높은 단계로 당사자들이 관계를 유지하기 위하여 의도적으로 자원을 개입시키는 톡징이 있는 단계인데, 당사자들간의 몰입은 이러한 몰입단계에 진입되면서 나타나게 된다. 신뢰를 위한 정직성이 구체적이고 가시적인 관계의 측면과 주로 관련되고, 따라서 몰입보다 좀 더 빨리 형성된다. 몰입은 관계를 미래의 관점에서 투영해보고, 또 좀 더 추상적인 기대에 근거하여 좀 더 포괄적으로 평가하는 것을 요구하며(Kumar 1996), 신뢰보다는 좀 더 많은 시간을 요구한다.

이러한 관점에서 인지적이고 가시적인 제품과 대리점 요소들이 신뢰에 영향요인으로 작용하였다고 판단되며, 서비스맨의 감정적 요소 그리고 거시적 변수로서 한전의 요금제도가 신뢰에 영향을 미치지 못하고 몰입에 영향을 미친 것으로 판단된다.

셋째, 기업에 대한 신뢰는 기업에 대한 몰입에 긍정적 영향을 미치는 것으로 나타넜다. 구체적으로 요소만족의 일부(심야전력제품에 대한 만족, 대리점시설에 대한 만족) 요인들이 몰입에 직접 영향을 미치지 않고 신뢰에 영향을 미친 다음 다시 이러한 신뢰가 몰입에 영향을 주었다. 즉, 신뢰가 요인별 만족과 몰입사이의 매개적 역할을 하고 있는 것이다.

넷째, 신뢰와 재구매 의도와의 관계는 유의적이지 않았다. 이는 신뢰가 곧바로 재구매 의도에 영향을 미치지 않고 몰입을 매개로 하여 간접적으로 영향을 미치는 것임을 보여준다.

\section{2. 실무적 시사점과 연구의 한계}

본 연구의 결과에 따라 다음과 같은 몇가지 실무적 시사점율 제시할 수 있으리라 생각된다

첫째, 심야전력고객을 대상으로 한 실무적 관점에서 보면 구체적 서비스요인에 대한 만족(심야전력요금제도에 대한 만족, 서비스맨에 대한 만족, 심야전력제품에 대한 만족, 
대리점시설에 대한 만족)과 기업에 대한 믈입간의 긍정적인 관계의 가설은 전반적인 만족의 경우와는 약간 달리 네 개의 요소중 심야전력요금제도에 대한 만족과 서비스맨에 대한 만족이 몰입과 정의 관계률 나타내고 있다. 이러한 결과는 기업에 대한 몰입요인은 심야전력상품의 품질과 대리점 시설 둥과 같은 물리적 요인보다는 공기업인 한전의 공익적 이미지와 서비스맨과 같은 인적 요인이 물입에 주 영향 요인임을 시사한다. 반면, 기업에 대한 신뢰요인은 전반적인 만족이나 몰입과는 달리 심야전력 제품에 대한 만족과 대리점에 대한 만족이 기업의 신뢰와 정의관계를 가지고 있는 것으로 나타나고 있다. 따라서 기업의 입장에서 고객의 몰입을 유도하기 위해서는 기업이 제공하는 기본적인 제품에 대한 만족뿐만 아니라, 고객이 중업원의 서비스나 태도, 친절 둥에 대한 만족이 선행되어야 하며, 이를 위해 종업원 교육이나 관리가 필요함을 시사한다고 할 수 있다.

둘째, 본 연구에서 제시한 바와 같이 심야전력제품이나 대리점에 대한 만족요인이 몰입에 직접 영향을 미치지 않고 신뢰를 퉁해 영향을 미치게 된다는 사실을 통해, 몰입에 앉서 신뢰는 제품의 질과 대리점 시설 둥과 같은 만족에서 기본적으로 구축되는 것을 알 수 있다. 따라서 장기적인 관계마케팅을 추구하는 기업의 입장에서는 심야제품에 대한 만족이나 대리점 만족을 퉁해 신뢰률 형성하고, 이률 퉁해 고객의 기업에 대한 몰입을 형성해 나가는 것이 펼요하다고 할 수 있다.

중합해 보면 거래관계외 초기단계에서는 제품자체에 대한 만족과 대리점의 서비스를 바탕으로 한 고객의 신뢰구축이 필요하고, 장기적으로는 적절한 전력요금제도와 서비스맨에 대한 대고객서비스를 지속적으로 강화함으로써 장기적인 고객관계를 형성할 수 있을 것으로 보인다. 또한 장기적인 관점에서 보면 거래초기의 고객에게는 전반적인 만족수준을 유지하도록 노력하며 고객과의 거래기간이 장기화되는 고객에게는 신뢰수준을 유지하면서 몰입을 유도할 수 있도록 전력요금제도의 정비와 서비스맨의 관리에 역점을 둘 필요가 있다.

위와 같은 본 연구의 요약과 시사점에도 블구하고 본 연구는 다음과 같은 한계점을 드러내고 있다. 이틀 바탕으로 하여 향후 연구방향을 모색하고자 한다.

첫째, 한전의 다양한 수요관리 방법과 제도 중에서 기저부하 중대(valley filling)인 축열식 심야전력제품인 전기보일러, 전기온돌과 같은 난방기기와 물긇이기 제품에 한정하였다.

둘째, 심야전력개발은 전기라는 제품을 공급하는 한전과 심야전력을 소비하는 심야전력용 제품을 판매하는 업체와 최종소비자간의 3 각 관계로 이루어지는 거래에 국한된 표본이기 매문에 실중분석한 결과를 경영학적 측면에서 일반화하는 데는 한계가 있다.

셋째, 설문 조사방법에 있어서 거래 직접 당사자인 한전 검침원이 고객을 면담 조사하여 평소 한전 검침원의 친숙도에 따라 우호적 또는 비우호적 답변 가능성이 있다.

넷째, 표본의 크기에 대한 문제로 모집단을 톡정지역 고객으로 한정함에 따라 비교적 서비스 체계가 잘되어 있는 대도시와 그렇지 못한 농어촌 지역간에는 연구 결과의 차이(gab)가 있을 수 있다.

다섯째, 매개변수에 미치는 영향요인 중에 한전의 심야전력요금제도와 서비스맨에 대한 만족은 몰입과의 관계에서는 유의적이고 신뢰와의 관계는 비유의적으로 나타난 반면, 심야전력제품 만족과 대리점 만족 요인은 신뢰와는 유의적이고 믈입과는 비유의적으로 나타났는데 이에 대한 더 깊은 연구가 필요하다.

여섯째, 구전의도에 대한 몰입과 신뢰의 효과는 검토되지 않았다. 따라서 구전의도와 몰입, 신뢰와의 관계를 검토하는 것도 반복적으로 연구되어야 할 추후 연구과제라고 하깄다. 
일곱째, 전반적 만족과 신뢰 및 몰입과의 관계설정 문제이다. 각 개념에 동일한 선행요인이 작용할 수 있으며, 또한 서로 다른 선행요인이 작용할 수도 있다. 전반적 만족은 요소별 만족보다 더 추상적이며 장기적 개념이기 때문에 전반적 만족과 신뢰 및 몰입간의 내용타당성을 검토하여 보완할 필요가 있다. 


\section{<참 고 문 헌>}

김주영, 함도훈, 김구성(2000), “경로구성원 쌍방의 독자적 신뢰에 대한 개념적 연구," 한국마케팅 저녈, 제2권 제2호, 13-37.

김재일, 이유재, 김주영(1996), “서비스산업의 현황과 서비스품질," 한국소비자학희

1996년도 홍희 및 학술대희 논문집, 1-57.

오세조, 박진용(1999), “소매업체와 공급업체의 신뢰 및 결속에 관한 연구," 한국유통학희 춘계학술발표 논문집, $155-183$

이유재, Richard P. Bagozzi(2000), "시도이론에 관한 이론적 연구:목표지향적 행동올 중심으로," 한국마케팅 저널, 제2권 제2호, 38-60.

한상린(1998), “산업재 공급자와 조직구매자간의 관계요인에 관한 연구," 마케텅 연구, 제13권 제 1호, 157-172

Anderson, Erin and Barton Weitz(1992), "The Use of Pledges to Build and Sustain Commitment in Distribution Channels," Journal of Marketing Research, 29(February), 18-34.

Anderson, Eugene W. Claes Fornell, and Donald R. Lehmann(1994), "Customer Satisfaction, Market Share, and Profitability : Findings from Sweden," Journal of Marketing, 58(July),53-66.

and James A. Narus(1991), "Partnering as a Focused Market Strategy," California Management

Review, 33 (Spring), 95-113.

Assael, Henry(1984), "Consumer Behavior and Marketing Action," Kent Publishing Company, 2nd ed., 412-413.

Barney, Jay B. (1990), "The Debate Between Traditional Management Theory and Organizational Economics," Academy of Management Review, 15(3), 382-94.

Becker, Howard S. (1960), "Notes on the Concept of Commitment," American Journal of Sociology, 66, 32-42.

Berry, Leonard L. (1995), "Relationship Marketing of Services Growing Interest, Emerging Perspectives," Journal of the Academy of Marketing Science, 23 (Fall), 236-45.

(1993), "Playing Fair in Retailing," Arthur Anderson Retailing Issues Newsletter (March), 5, 2. and A. Parasuraman (1991), Marketing Services. New York: The Free Press.

Bettencourt, Lance A. (1997), "Customer Voluntary Performance: Customers as Partners in Service Delivery," Journal of Retailing, 73 (Fall), 383-406.

Bhattacharya, C.B., Hayagreeva Rao, and Mary Ann Glynn(1995), "Understanding the Bond of Identification: An Investigation of Its Correlates Among Art Museum Members," Journal of Marketing, 59 (October), 46-57.

Bitner, Mary Jo (1990), "Evaluating Service Encounters : The Effects of Physical Surroundings and Employee Responses," Journal of Marketing, 54 (April), 69-82.

Caldwell, David F., Jennifer A. Chatman, and Charles A. O'Reilly (1990), "Building Organizational Commitment: A Multifirm Study,"Journal of Occupational Psychology, 63, 245-61.

Carlston, Donal E. (1980), "The Recall and Use of Traits and Events in Social Inference Processes," Journal of Experimental Social Psychology, 16(2), 302-28.

Crosby, Lawrence A., Kenneth R. Evans, and Deborah Cowles (1990), "Relationship Quality in Services Selling: An Interpersonal Influence Perspective," Journal of Maketing, 54 (July), 68-81.

and Nancy Stephens (1987), "Effects of Relationship Marketing on Satisfaction, Retention and

Prices in the Life Insurance," Journal of Marketing Research, 24 (November), 404-11.

Czepiel, John A. (1990), "Service Encounters and Service Relationships: Implications for Research," Journal of Business Research, 20(1), 13-21. 
Larry J. Rosenberg, and Adebayo Akerele (1974), "Perspectives on Consumer Satisfaction," in AMA Educators' Proceedings. Chicago: American Marketing Association, 119-23.

Donaldson, Lex (1990), "A Rational Basis for Criticisms of Industrial Organization Economics," Academy of Management Review, 15(3), 394-401.

Dwyer, F. Robert, Paul H. Schurr, and Sejo Oh (1987), "Developing Buyer-Seller Relationships," Journal of Marketing, 51 (April), 11-27.

Eisenberger, Robert, Peter Fasolo, and Valerie Davis-LaMastro(1990), "Perceived Organizational Support and Employee Diligence, Commitment, and Innovation," Journal of Applied Psychology, 75(1), 51-59.

Ford, David (1990), Understanding Business Markets: Interaction, Relationships, and Networks. London: Academic Press.

Fournier, Susan, Susan Dobscha, and David Glen Mick (1998), "Preventing the Premature Death of Relationship Marketing," Harvard Business Review, 76 (January/February), 42-50.

Fox, A. (1974), Beyond Contract: Work, Power and Trust Relationships. London: Faber.

Garbarino, Ellen and Mark S. Johnson (1999), "The Different Roles of Satisfaction, Trust, and Commitment in Customer Relationships," Journal of Marketing, 63(April), 70-87.

Gundlach, Gregory T., Ravi S. Achrol, and John T. Mentzer (1995), "The Structure of Commitment in Exchange," Journal of Marketing, 59(January), 78-92.

Gwinner, Kevin P., Dwayne D. Gremler, and Mary Jo Bitner (1998), "Relational Benefits in Service Industries: The Customer's Perspective," Journal of the Academy of Marketing Science, 26 (Spring), 101-14.

Hakansson, Haken, ed. (1982), International Marketing and Purchasing of Industrial Goods: An Interaction Approach. Chichester, England: John Wiley and Sons, Ltd.

Hawkins, Dell I., Roger J. Best, and Kenneth A. Coney(1986). Consumer Behavior Strategy: Implication for Marketing Review, Vol. 17, No 2, 183-211

Hofstede, G.(1980), Culture's Consequences, Newbury Park, CA: Sage Publications.

Hovland, C. E., I. L. Janis, and Harold H. Kelley (1953), Communication and Persuasion. New Haven, CT: Yale University Press.

Hrebiniak, Lawrence G. (1974), "Effects of Job Level and Participation on Employee Attitudes and Perceptions of Influence," Academy of Management Journal, 17, 649-62.

Jackson, Barbara B. (1985), Winning and Keeping Industrial Customer: The Dynamics of Customer Relationships. Lexington, MA: D.C. Heath and Company.

Joreskog, Karl G. and Dag Sorbom (1993), Lisrel 8: A Guide to the Program and Applications. Chicago: SPSS.

Kelley, Scott W. and Mark A. Davis (1994), "Antecedents to Customer Expectations for Service, Recovery," Journal of the Academy of Marketing Science, 22 (Winter), 52-61.

Kumar, Nirmalya(1996), "The Power of Trust in Manufacture-Retailer Relationships," Harvard Business Review, 74(November/December), 92-106.

Macneil, Ian (1980), The New Social Contract, An Inquiry into Modern Contractual Relations. New Haven, CT: Yale University Press.

Mathieu, J. E. and D. M. Zajac (1990), "A Review and Meta-analysis of the Antecedents, Correlates, and Consequences of Organizational Commitment," Psychological Bulletin, 108, 171-94.

McDonald, Gerald W. (1981), "Structural Exchange and Marital Interaction," Journal of Marriage and the Family(November), 825-39.

Mittal, Vikas, William T. Ross Jr., and Patrick M. Baldasare (1998)," The Asymmetric Impact of Negative and Positive Attribute-Level Performance on Overall Satisfaction and Repurchase Intentions," Journal of Marketing, 62 (January), 33-47. 
Moorman, Christine, Rohit Deshpande, and Gerald Zaltman (1993), "Factors Affecting Trust in Market Relationships," Journal of Marketing, 57 (January), 81-101. , Gerald Zaltman, and Rohit Deshpande (1992), " Relationships Between Providers and Users of Market Research: The Dynamics of Trust Within and Between Organizations," Journal of Marketing Research, 29 (August), 314-29.

Morngan, Robeat M. and Shelby D. Hunt (1994), "The Commitment Trust Theory of Relationship Marketing," Journal of Marketing, 58 (July), 20-38.

Oliver, Richard L. (1993), "Cognitive, Affective, and Attribute Bases of the Satisfaction Response," Journal of Consumer Research, 20 (December), 418-30.

O'Reilly, Charles, III and Jennifer Chatman (1986)," Organizational Commitment and Psychological Attachment: The Effects of Compliance, Identification, Internalization on Prosocial Behaviors," Journal of Applied Psychology, 71 (3), 492-99.

Ostrom, Amy and Dawn Iacobucci (1995), "Consumer Trade-Offs and the Evaluation of Services," Journal of Marketing, 59(January), 17-28.

Podsakoff, Philip M., and Scott B. MacKenzie., R. H. Moorman, and Richard Fetter (1990), "Transformational Leader Behaviors and Their Effects on Followers' Trust in Leader, Satisfaction, and Organizational Citizenship Behaviors," Leadership Quarterly 1(Summer): 107-142.

Porter, Lyman W., Richard M. Steers, Richard T. Mowday, and Paul V. Boulian (1974), "Organizational Commitment, Job Satisfaction, and Turnover Among Psychiatric Technicians," Journal of Applied Psychology, 59, 603-9.

Price, Linda L., Eric J. Arnould, and Patrick Tierney, (1995)," Going to Extremes: Managing Service Encounters and Assessing Provider Performance," Journal of Marketing, 59 (April), 83-97.

Rust, Roland T., Anthony J. Zahorik, and Timothy L. Keiningham(1995), "Return on Quality (ROQ): Making Service Quality Financially Accountable," Journal of Marketing, 59 (April) 58-70.

Reichers, A. E. (1985), "A Review and Reconceptualization of Organizational Commitment," Academy of Management Review, 10, 465-76.

Scanzoni, John (1979), "Social Exchange and Behavioral Independence," in Social Exchange in Developing Relationships, R. L. Burgess and T. L. Huston, eds. New York: Academic Press.

Schurr, Paul H. and Julie L. Ozanne (1985), "Influences on Exchange Processes: Buyers' Preconceptions of a Seller's Trustworthiness and Bargaining Toughness," Journal of Consumer Research, 11(March), 939-53.

Sherman, Stralford (1992), "Are Strategic Alliances Working?," Fortune (September), 77-78.

Speckman, Robert E. (1988), "Strategic Supplier Selection: Understanding Long-Term Buyer Relationships," Business Horizons, (July/August), 75-81.

Spreng, Richard A., Scott B. MacKenzie, and Richard W. Olshavsky(1996), " A Reexamination of the Determinants of Consumer Satisfaction," Journal of Marketing, 60 (July), 15-32.

Steers, Richard M. (1977), "Antecedents and Outcomes of Organizational Commitment," Administrative Sciences Quarterly, 22 (March), 46-56.

Webster, Frederick E. Jr. (1992), "The Changing Role of Marketing in the Corporation," Journal of Marketing, 56 (October), 1-17.

Westbrook, Robert A.(1981), "Sources of Satisfaction with Retail Outlets," Journal of Retailing, 57 (Fall), 68-85.

Williams, Larry J. and John T. Hazer (1986), "Antecedents and Consequences of Satisfaction and Commitment in Trust Models: A Reanalysis Using Latent Variable Structural Equations Methods," Journal of Applied Psychology, 71 (2), 219-23. 
Zeithaml, Valerie A., Leonard L. Berry, and A. Parasuraman (1996), "The Behavioral Consequences of Service Quality," Journal of Marketing, 60(April), 31-46. 